\title{
Aspects of the Life of Colmán of Lynn
}

\section{Gavin Dillon}

Roinn na Sean- $\beta$ na Meán-Ghaeilge, UCC - Department of Early and Medieval Irish, UCC

\section{Introduction and Background}

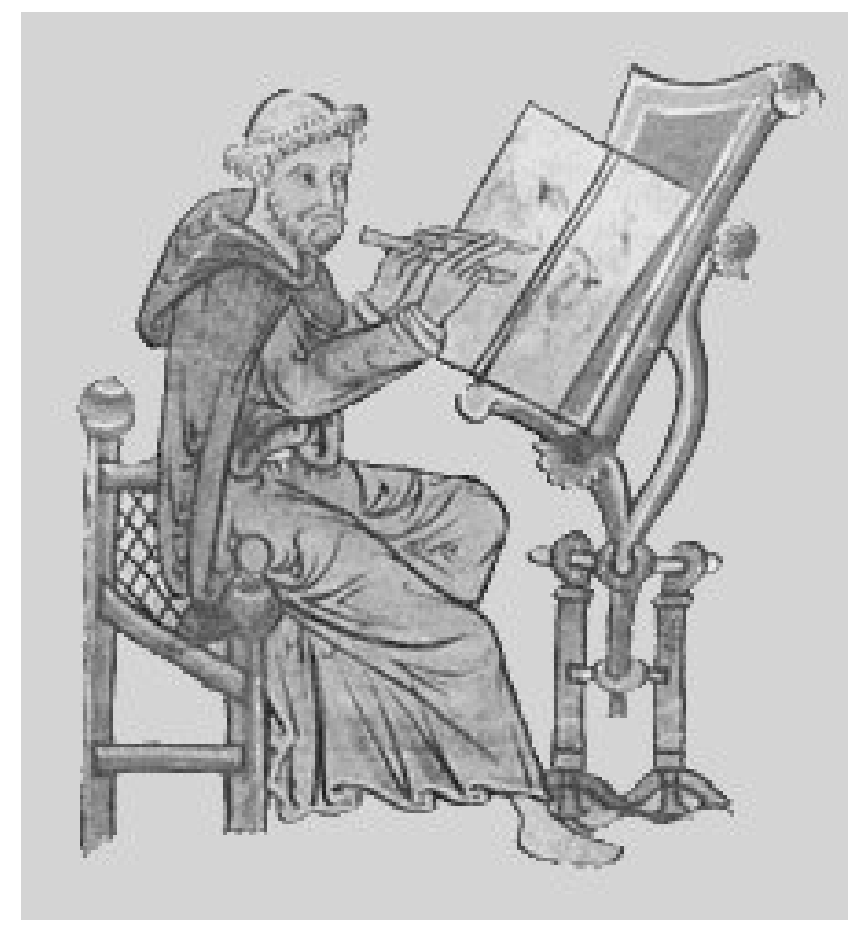

Figure 1: The medieval hagiographer at work in the scriptorium

Hagiography is narrative material relating to the saints. This may take various forms, including poetry and prose tales, but most often it consists of the written Life of a saint. From the outset it is to be kept in mind that a 'Life' of a saint does not necessarily equate to a biography, though it may contain biographical information. Rather, it is useful to view hagiography as containing as much, if not more, information about those who composed it than it does about its subject saint. Saints' Lives provide a useful window into concerns and issues important to the communities in which, or for which, they were produced. A Life composed in the twelfth century may therefore allow us great insight into the politics, policies, religious and world-views of the twelfth-century society in which the Life was composed, but tell us relatively little about the saint and society of the seventh-century setting. 
The Life of Colmán son of Lúachán is a little-studied example of such a work set largely in the seventh century but composed in the twelfth century. The only surviving version of it is a fifteenth-century copy of the original in a manuscript currently stored in Rennes. The text was composed at the monastic settlement of Lann Mhic Lúacháin, present day Lynn, a few miles south of Mullingar. It is an unusually lengthy Life, considering it was produced by a community about which very little is known, and which most likely did not have much influence in the midlands of the twelfth century. Given this, it is odd that detailed analysis of it has not, to date, been undertaken. Thus it greatly merited the current research. The Life is composed in Irish using a mixture of prose and verse, the latter often being used to reiterate or expand upon certain episodes. A wealth of information is contained therein on topics such as miracles, property claims and transactions, tribute, historical information and the political stance of the community regarding both secular and ecclesiastical neighbours. The current paper seeks to highlight its revelations about the microcosm of Lynn in the twelfth century, extending the evidence available from historical and archaeological sources.

The concerns of a small midlands monastic community in the twelfth century would have reflected the concerns of the wider community of the time. Great upheaval was occurring in both church and state during the eleventh and twelfth centuries. In the century following the death of Brían Bóroma in 1014, political stability was often threatened as numerous provincial kings began to vie for the kingship of Ireland over an extended period of constant conflict and shifting alliances. The church too was undergoing vast change. It had become wealthy and highly involved in secular affairs, to the point that it was said that the numerous powerful churches of the midlands possessed more property and wealth between them than the kings did. Reform from Europe had begun to spread in Ireland, centred largely in Munster and thereafter Armagh, chief church of St. Patrick. Many churches, especially those in the midlands, resisted such reform, having become accustomed to high status and wealth. The continuing expansion of some of the larger churches saw smaller communities swallowed up and saw tensions arise over property between churches, and indeed between church and state.

\section{Concerns of the Life}

\section{Property, Land, Wealth}

A preoccupation with property in the Life of Colmán highlights a primary concern of the community at Lynn during this period. Numerous episodes in the Life recall how the saint performed some miracle for a local ruler and was granted property or tribute in return. Sometimes the saint only has to ask the king for land, citing the need to build another church, and his request is granted. In return, the secular ruler is blessed with good luck 
in battle and harvest. In the majority of these cases, the land acquired, or tribute agreed upon, is detailed minutely, including dimensions and boundaries of property, with long and very precise descriptions of tribute to be given at particular times of the year. Notably, the majority of property transactions are claimed to be free of tax for Colmán, and his successors, 'until doom'. The mention of the successors is important, as it allows the community at Lynn to validate their claim over everything originally due to the saint. This is a common and useful motif in hagiography whereby concerns of the contemporary present are, via the Life, reflected into the past to give them (an often false) authority.

Much previous scholarship has come to the conclusion that, due to the large proportion of the text making some form of property or tribute claim, Lynn must have been ambitiously, if not shamelessly, portraying itself as being on par with far larger and more influential midland ecclesiastical centres such as Clonmacnoise, Durrow, Rahan and Clonard, all of which were in close proximity to their smaller neighbour. It has also been assumed that grandiose claims were a desperate attempt, in a time of upheaval, to extend the influence of the church at Lynn. This has been a generally accepted opinion in the last century since the Life was first edited and translated. However, in light of existing work on placename identification, and in conjunction with modern cartographic knowledge, it has been possible to identify, locate and map far more of the numerous place names in the text than hitherto expected. This has produced an image of the claims of Lynn quite different from what had previously been accepted. What has emerged is a far more localised area of concern, stretching to a maximum radius of about eleven kilometres. Rather than seeing an ambitious establishment seeking to claim tribute and property far beyond the realistic, we see a church vehemently consolidating what was likely already under its influence. Its focus is on the local community of which it was an important part. Analysis of the tribute claimed to be due to the church supports this, as food, drink, clothing and animals due at particular times of the year are detailed. Indeed, it would seem that every individual in the locality was obliged to provide some offering to the church. However, large claims of gold, silver and other articles of wealth are absent.

\section{Lynn and its Secular Neighbours}

Given the aforementioned context of tensions and upheavals, a picture is painted of a church reminding its locality that such-and-such an area of land belongs to it, and to noone else, reminding them that, at certain times of the year, such-and-such tribute is due from them so as not to risk the wrath of Saint Colmán. The same reminder is made to local rulers of the twelfth century, whose ancestors are depicted in the Life in varyingly positive or negative lights, depending on their conduct in relation to Colmán. Rulers who give freely of tribute and property are saved from death, rejuvenated or granted victory in battle. Those that transgress against saint are cursed, sometimes having their forts destroyed; sometimes the saint promises that their descendents will lose the kingship for 
a number of generations until apology is made. Here, the author of the Life displays his knowledge of history. In one example the historical sources do record that a certain king lost the kingship for three generations before it was restored, which corresponds with what the author has claimed was a curse by Colmán. Again, contemporary information is projected into the past to give it authority. The king in the twelfth century is reminded that perhaps he owes his kingship to the magnanimity of the saint.

The relationship between Lynn, its surrounding local kingships, over-kingships and other, more influential, ecclesiastical centres is inextricable. Aside from the relationships portrayed directly between Lynn and surrounding kings, the Life also provides much information on the relations between the local, less influential, rulers and their overlords, allowing a glimpse into local politics which is not available from other sources. The local rulers of the area immediately surrounding Lynn were the Fir Tulach. Their over-kings were the southern branch of the Uí Néill, Clann Cholmáin, a very influential family on a national stage. One episode in the Life relates how the Fir Tulach used to have their residence on a certain island-fort until it was taken from them by Clann Cholmáin (whose king at the time incidentally stole the Fir Tulach king's wife). The Fir Tulach king was outraged by this, according to the Life. Historical sources mention clearly that the island fortress was used by the Clann Cholmáin in the eleventh century, but do not mention how they came to use it. If the information in the Life is to be believed, this and other episodes can help to greatly increase our knowledge of the politics and history of the midlands of the early medieval period.

\section{Lynn and its Ecclesiastical Neighbours}

Tension between churches in the midlands is also demonstrated in the Life. The aforementioned Clonmacnoise was undergoing a period of aggressive expansion in the eleventh and early twelfth centuries, and seems to have come into conflict with Lynn. This is depicted in an episode where Ciarán, patron of Clonmacnoise, visits Colmán to request that the latter acknowledge him as his superior. Colmán refuses, stating that he will acknowledge no-one other than Mochuta as his superior. Mochuta was patron of Rahan, a large and influential church close to Lynn. Through this episode, we may read that Lynn sought to ally itself with Rahan to bolster its position against the expanding Clonmacnoise, which may have been seeking, or bordering on, properties claimed by Lynn. None of this information appears in the historical sources, and it is always necessary to keep in mind the political agenda with which the author is working when considering its reliability. Nevertheless such information adds further depth to our understanding of the intricacies of church politics of the twelfth century. 


\section{Incidental Information in the Life}

Much incidental information on daily life and the social construction of Lynn may also be extrapolated from the Life of Colmán. Key positions within the church are described, such as the abbot, or successor to the saint, the steward-family of the church and its chief craftsman, a position of great esteem at the time. We are also told what meals were to be eaten on certain festival days, and how milk should only be drunk at such times under the unfortunate circumstance of having run out of ale. The tale of how Mullingar, in County Westmeath, acquired its name is also contained in the Life, the only source for this information. In this episode, Colmán causes a miracle to occur in which the stone of the mill grinding corn to flour grinds the opposite way to its usual course, hence Mullingar, Muillenn Cerr, the Backwards Mill.

\section{Summary}

The preceding information gives only a glimpse of the depth and scope of the Life of Colmán to serve as an introduction to the research being undertaken on the text, as well as to outline the importance of studies in hagiography. Reading such texts in the context of their accepted conventions, and historical standpoint, it is possible to peel away the strata and reveal at least some of what they have to tell us about the time in which they were composed. By comparing and contrasting them with archaeological and historical material, it is possible to tell what is historically accurate or inaccurate. Inaccuracies are not to be immediately viewed as flaws, as has previously been the case. Rather it may be asked why the authors of hagiography chose to include chronologically, or otherwise, inconsistent material? This method of questioning can help to go beyond that which is historical, providing insight into the psychology and political and social interactions of the period. Thus the texts may reveal an ever clearer and more detailed insight into medieval Ireland's rich cultural heritage.

\section{Suggested Reading}

For those with an interest in the Life of Colmán, I would point you to:

The Life of Colmán of Lynn, Betha Colmáin Lainne, ed. L. Daly, trans. K. Meyer, (Dublin, 1999).

For a general overview of Irish history and political dynasties, the following is excellent: Byrne, F.J. Irish Kings and High Kings, (London, 1973).

Gavin Dillon is a student of Roinn na Sean- agus na Meán-Ghaeilge, Department of Early and Medieval Irish, under the supervision of Professor Máire Herbert. The author would like to acknowledge the support, kindness and wisdom of the staff and postgraduate students of the department. 